\title{
EFFECT OF LATERAL POSITION AND VOLUME ON THE SPREAD OF EPIDURAL ANAESTHESIA IN THE PARTURIENT
}

\author{
Stephen H. Rolbin, A.F. D. Cole, Ernest M. Hew and Susan Virgint
}

\begin{abstract}
The effect of lateral positioning and the volume of drug injected on the spread of epidural anaesthesia was assessed in 131 healt hy parturients.

Epidural injection for anaesthesia was done at the L3-4 interspace and a catheter was inserted into the epidural space after injection of the drug. The patients were randomly assigned to four groups. The doses used were $12 \mathrm{ml}$ of bupivacaine 0.25 per cent and $6 \mathrm{ml}$ of bupivacaine 0.5 per cent. Patients were kept in the lateral position in which the block was done (Groups I and III) or turned to the opposite side after completion of the epidural injection (Groups II and IV). Sensory levels and maternal assessment of pain relief were determined fifteen to twenty minutes after injection. All assessments were done by a trained observer who did not know to what group the patient had been allocated.

Maintenance of the lateral position after induction of epidural anaesthesia is compatible with satisfactory analgesia for labour. Twelve $\mathrm{ml}$ bupivacaine 0.25 per cent provides better analgesia than $6 \mathrm{ml}$ bupivacaine 0.5 per cent although the same mass is injected. The quality of analgesia is improved by turning the patients to the contralateral side after injection of $12 \mathrm{ml}$ bupivacaine 0.25 per cent.
\end{abstract}

Key Words: ANAESTHesia, Obstetrical; ANAESTHETIC TECHNiques, Epidural.

IT is NOW ACCEPTED that the parturient should not be placed supine because of the risk of aorto-caval compression. ${ }^{1-3}$ This risk may be increased after administration of epidural anaesthesia. ${ }^{4.5}$

We wished to determine the effects of lateral positioning and the volume of drug injected on the efficacy and spread of epidural anaesthesia during labour. We were persuaded to do this stu dy because we understood that certain centers, in Canada at any rate, still place parturients in the supine position. They do so because they believe analgesia would be less effective if the mother is placed in the lateral position.

\section{METHOD}

One hundred and thirty-one patients were studied. All patients were ASA physical status 1

Stephen H. Rolbin, M.D., C.M., F.R.C.P.(C), CoDirector, Obstetrical Anaesthesia, Assistant Professor of Anaesthesia; A.F.D. Cole, M.D., F.R.C.P.(C), CoDirector, Obstetrical Anaesthesia, Assistant Professor of Anacsthesia; Ernest M. Hew, M.D., F.R.C.P.(C), F.F.A.R.C.S.(I), Co-Director, Intensive Care Unit, Associate Professor of Anaesthesia; Susan Virgint, R.R.T., Research Technologist.

Department of Anaesthesia, University of Toronto and Mount Sinai Hospital.

Reprint requests to: Dr. S. Rolbin, Department of Anaesthesia, Mount Sinai Hospital, 600 University Avenue, Toronto, Ontario, M5G IX5. and in the first stage of labour. Consent was obtained for anaesthesia and subsequent examination. Patients were placed on either one or the other side and the epidural injection was done using a 16-guage Tuohy needle at the L 3-4 interspace. No test dose was given. A catheter was inserted $3-4 \mathrm{~cm}$ into the epidural space after the injection. The doses used were $12 \mathrm{ml}$ of bupivacaine 0.25 per cent and $6 \mathrm{ml}$ of bupivacaine 0.5 per cent (Table I). Thus all patients received bupivacaine $30 \mathrm{mg}$. At random, the patients were kept in the lateral position on the same side on whic $h$ the injection was done (groups I and III) or turned to the opposite side after completion of the epidural injection (groups II and IV). The turning was done within two to four minutes of the injection and all patients remained in the lateral position thoughout labour.

Fifteen to twenty minutes after injection, the analgesia was assessed and the sensory levels were noted. All assessments were made by a trained observer who did not know to what group the patient had been allocated. The patients were also unaware as to whether they received $6 \mathrm{ml}$ of drug or $12 \mathrm{ml}$ of drug. The upper and lower dermatome levels of anaesthesia ${ }^{6}$ were measured by testing for loss of sharpness to pinprick (\#22 s.w.g. needle) in both dependent and nondependent sides of the body. The terms dependent and non-dependent refer to the body position 
TABLE I

Grouping of Patients Studied

\begin{tabular}{|c|c|c|c|c|}
\hline \multirow[b]{2}{*}{ Group } & \multicolumn{2}{|c|}{ Bupivacaine } & \multirow[b]{2}{*}{ Position } & \multirow[b]{2}{*}{ Number } \\
\hline & Volume & Concentration & & \\
\hline I & $12 \mathrm{ml}$ & $0.25 \%$ & Not Turned & 50 \\
\hline II & $12 \mathrm{ml}$ & $0.25 \%$ & Turned & 50 \\
\hline III & $6 \mathrm{ml}$ & $0.5 \%$ & Not Turned & 15 \\
\hline IV & $6 \mathrm{ml}$ & $0.5 \%$ & Turned & 16 \\
\hline
\end{tabular}

at the time of assessment not at the time of epidural administration. The effects of turning and volume on the number of segments blocked were assessed by two-way analysis of variance. The effects of height and weight on the number of dermatomes blocked were assessed by simple linear regression.

Analgesia was assessed by the mother using a five point scale 7 in which $4+$ represents complete pain relief, $3+$ some pain but a satisfied patient, $2+$ definitely helped but not satisfied, $1+$ hardly any relief and zero as no pain relief. The analgesic scores were assessed by chi-square analysis. The interaction between concentration and/or volume and analgesic score were assessed by likelihood ratio test. The calculation were done using GLIM, a statistical system prepared by the Royal Statistical Society. ${ }^{8}$

At the time of assessment, each patient was asked directly if she wished a supplementary dose of local anaesthetic. Supplementary drugs were then given as requested.

\section{Results}

The four groups were comparable as to parity, height, weight, cervical dilatation and station when the epidural was initiated (Table II).

After initiating the study it became apparent that some of the patients had very poor pain relief. Indeed, after preliminary analysis of the data, the two groups with $6 \mathrm{ml}$ of bupivacaine 0.5 per cent were discontinued due to the poor analgesia obtained.

The effects of turning and volume were assessed as to the number of segments blocked on both the dependent and non-dependent sides of the body (Table III). Both volume and turning prove to be significant factors influencing the number of segments blocked on the dependent side of the body (Table IV). However, on the nondependent side only volume significantly increases the number of segments blocked.
It is of interest to note that there is no significant correlation between the number of segments blocked and the weight or height of the patient (Table V). However, because the range of weights and heights was small (Table II), a positive correlation might not be expected.

The measurement of upper and lower levels only will clearly not delineate those segments which remain poorly or incompletely blocked and, therefore, the figures quoted may be misleading. The analgesia scores, therefore, were used to document the mother's assessment of her pain relief and thus represent a clinically pertinent factor. The results of the analgesia scores with $12 \mathrm{ml}$ of bupivacaine 0.25 per cent both turned and not turned (groups I and II), indicated that the vast majority of patients were satisfied (Table VI). This is in contrast to a much lower percentage in patients receiving $6 \mathrm{ml}$ of bupivacaine 0.5 per cent. By turning the patients who received $12 \mathrm{ml}$ of bupivacaine 0.25 per cent, the likelihood of the patient having perfect or complete (only $4+$ ) pain relief increased by 28 per cent (Table VI). The p-value attained by chi-square analysis was less than 0.001 .

The pain relief with $6 \mathrm{ml}$ of bupivacaine 0.5 per cent whether turned or not turned (groups III and IV) was inferior to the pain relief achieved with $12 \mathrm{ml}$ of bupivacaine 0.25 per cent (Table VI). There was a 50 per cent rate of dissatisfaction (i.e. 0 to $2+$ ), in both groups receiving $6 \mathrm{ml}$ of bupivacaine.

The dependence of pain relief (i.e. analgesia scores) on turning and/or volume either together or alone was assessed by likelihood ratio test (Table VII). The entries in this table are $\chi^{2}$ equivalents of the likelihood ratio test. The $\chi^{2}$ values are given together with their degrees of freedom and $p$-values. The data indicated that the quality of pain relief depends on the volume of drug injected and on whether the patient was turned to the opposite side after the epidural injection. In addition, positioning and volume had effects which operated independently of each other.

Twelve $\mathrm{ml}$ of bupivacaine 0.25 per cent was superior to $6 \mathrm{ml}$ of bupivacaine 0.5 per cent. More than 30 per cent of the patients who received $6 \mathrm{ml}$ of bupivacaine 0.5 per cent requested supplementary doses. While only eight per cent of the patients who received $12 \mathrm{ml}$ bupivacaine $0.25 \mathrm{per}$ cent (groups I and II) requested more pain relief. All patients who received supplementary doses of bupivacaine were given 5 to $10 \mathrm{ml}$ of bupivacaine 
TABLE II

Clinical Data of Patients Studied

\begin{tabular}{|c|c|c|c|c|c|c|c|c|c|}
\hline \multirow{2}{*}{$\begin{array}{l}\text { Variable } \\
\text { Factor }\end{array}$} & \multicolumn{2}{|c|}{ Group I } & \multicolumn{2}{|c|}{ Group II } & \multicolumn{2}{|c|}{ Group III } & \multicolumn{2}{|c|}{ Group IV } & \multirow[b]{2}{*}{$\mathrm{Pt}$} \\
\hline & Mean* & Range & Mean* & Range & Mcan* & Range & Mean* & Range & \\
\hline Height $\mathrm{cm}$ & $162 \pm 1.0$ & $149-183$ & $161 \pm 1.0$ & $147-178$ & $161 \pm 1.2$ & $152-170$ & $161 \pm 2.0$ & $148-175$ & 0.6 \\
\hline W'eight kg & $70 \pm 1.4$ & $52-95$ & $70 \pm 1.8$ & $54-107$ & $70 \pm 3.2$ & $59-108$ & $71 \pm 2.3$ & $59-84$ & 0.98 \\
\hline rerv. Dil. cm & $5 \pm 0.3$ & $1-7$ & $5 \pm 0.3$ & $1-8$ & $5 \pm 0.4$ & $3-9$ & $5 \pm 0.4$ & $3-8$ & 0.38 \\
\hline Station $\mathrm{cm}$ & $-0.6 \pm 0.15$ & 0.2 to +2 & $0.7 \pm 1.15$ & -2 to +1 & $-0.7 \pm 0.25$ & -2 to +1 & $0.8 \pm 0.24$ & -2 to +1 & 0.279 \\
\hline
\end{tabular}

Groups as in Table I.

*Mean \pm S.E.

†One way analysis of variance.

TABLE III

ThE INFLUENCE OF TURNING and VOLUME ON THE Number of Segments Blocked

\begin{tabular}{cccccc}
\hline & \multicolumn{2}{c}{ Dependent } & & \multicolumn{2}{c}{ Non-dependent } \\
\cline { 2 - 3 } \cline { 5 - 6 } Group & $\begin{array}{c}\text { Number } \\
\text { Segments }\end{array}$ & Range & & $\begin{array}{c}\text { Number of } \\
\text { Segments }\end{array}$ & Range \\
\hline I & 5.8 & T4-S5 & & 5.0 & T4-S4 \\
II & 4.3 & T7-L4 & & 4.3 & T7-LLS \\
III & 5.1 & T10-L5 & & 3.4 & T10-L5 \\
IV & 2.8 & T9-L3 & & 3.4 & T9-L2 \\
\hline
\end{tabular}

Groups as in Table I.

TABLE IV

ANALYSIS OF THE INFLUENCE OF TURNING AND VOLUME ON THE NUMBER OF SEGMENTS Blocked*

\begin{tabular}{lcc}
\hline $\begin{array}{c}\text { Factors } \\
\text { Assessed }\end{array}$ & $\begin{array}{c}\text { Dependent } \\
\text { Side }\end{array}$ & $\begin{array}{c}\text { Non-dependent } \\
\text { Side }\end{array}$ \\
\hline Turning & $\mathrm{p}=0.0001^{\dagger}$ & $\mathrm{p}=0.1960$ \\
Volume & $\mathrm{p}=0.0346^{\dagger}$ & $\mathrm{p}=0.0134 \dagger$ \\
\hline
\end{tabular}

*Two way analysis of variance.

†Significant.

0.25 per cent and then turned to face in the opposite direction. All patients then obtained satisfactory pain relief.

\section{Discussion}

We have demonstrated that maintenance of the lateral position after epidural anaesthesia is compatible with satisfactory analgesia for labour. There is thus no valid reason for the supine position in a parturient after initiation of epidural anaesthesia. Turning the patient to the contralateral position after injection of $12 \mathrm{ml}$ of bupivacaine 0.25 per cent improved the quality of analgesia.
TABLE V

EFFECT OF HEIGHT AND WEIGHT ON THE NUMBER OF SEGMENTS BLOCKED

\begin{tabular}{clc}
\hline & Dependent & Non-dependent \\
\hline Weight R* & 0.04516 & 0.10946 \\
P & 0.5214 & 0.2421 \\
Height R & 0.11283 & 0.08097 \\
P & 0.2179 & 0.3897 \\
\hline
\end{tabular}

*Correlation coefficient

t $\mathrm{p}$ value or level of significance

TABLE VI

Pain Relief Scores: Percentage of Patients WITH EACH ANALgesia SCORE

\begin{tabular}{cccc}
\hline \hline Group & $\begin{array}{c}\text { Analgesia } \\
\text { Scores }\end{array}$ & $\begin{array}{c}\text { Dependent } \\
\text { Side }\end{array}$ & $\begin{array}{c}\text { Non-dependent } \\
\text { Side }\end{array}$ \\
\hline I & $4+$ & 88 & 56 \\
& $3+$ & 6 & 34 \\
& $0-2+$ & 6 & 10 \\
II & $4+$ & 80 & 84 \\
& $3+$ & 14 & 12 \\
& $0-2+$ & 6 & 4 \\
III & $4+$ & 67 & 46 \\
& $3+$ & 26 & 21 \\
& $0-2+$ & 7 & 33 \\
IV & $4+$ & 50 & 50 \\
& $3+$ & 25 & 19 \\
& $0-2+$ & 25 & 31
\end{tabular}

Groups as in Table I.

Grundy, et al..$^{9}$ found that gravity played a definite role in the spread of epidural agents. They injected $150 \mathrm{mg}$ of bupivacaine while the patient was in the lateral position and noted that the spread of analgesia was two segments higher on the dependent side. Although we used only $30 \mathrm{mg}$ of bupivacaine, our results confirm the importance of gravity on the spread of epidural analgesia. 
TABLE VII

The Determinants of Pain Relief with 30 MG Bupivacaine

\begin{tabular}{|c|c|c|c|c|c|c|c|c|}
\hline \multirow{2}{*}{\multicolumn{2}{|c|}{ Hypothesis Tested }} & \multicolumn{3}{|c|}{$\begin{array}{c}\text { Dependent } \\
\text { Side of Body }\end{array}$} & \multicolumn{3}{|c|}{$\begin{array}{l}\text { Non-dependent } \\
\text { Side of Body }\end{array}$} & \multirow[b]{2}{*}{ Conclusion } \\
\hline & & $\begin{array}{l}\text { Likelihood } \\
\text { Ratio } \chi^{2}\end{array}$ & $\mathrm{df}^{*}$ & $\mathbf{P}$ & $\begin{array}{l}\text { Likelihood } \\
\text { Ratio } \chi^{2}\end{array}$ & $\mathrm{~d} f^{*}$ & $\mathrm{P}$ & \\
\hline I & $\begin{array}{l}\text { Pain relief does not } \\
\text { depend on volume } \\
\text { but on turning } \\
\text { alone }\end{array}$ & 10.29 & 4 & $<0.05$ & 13.74 & 4 & $<0.01$ & $\begin{array}{l}\text { Pain relief does depend on } \\
\text { volume }\end{array}$ \\
\hline II & $\begin{array}{l}\text { Pain relief does not } \\
\text { depend on turning } \\
\text { but on volume } \\
\text { alone }\end{array}$ & 3.954 & 4 & $<0.5$ & 9.664 & 4 & $<0.05$ & $\begin{array}{l}\text { Only in the non-dependent } \\
\text { side of the body does } \\
\text { pain relief depend on } \\
\text { turning }\end{array}$ \\
\hline & $\begin{array}{l}\text { I The effectiveness } \\
\text { of turning does not } \\
\text { depend on volume } \\
\text { injected }\end{array}$ & 1.854 & 2 & $<0.5$ & 1.938 & 2 & $<0.5$ & $\begin{array}{l}\text { Turning and volume have } \\
\text { effects which operate } \\
\text { independently in pro- } \\
\text { viding pain relief }\end{array}$ \\
\hline
\end{tabular}

*Degrees of freedom

While assessing spread of epidural anaesthesia in pregnancy, Sharrock ${ }^{10}$ calculated that $8-12 \mathrm{ml}$ of local anaesthetic agent should provide painfree labour and delivery. Bleyaert, et al. ${ }^{11}$ using $10 \mathrm{ml}$ of bupivacaine 0.125 per cent with epinephrine $1: 800,000$, obtained satisfactory analgesia in only 83 per cent of patients. After a further dose of $10 \mathrm{ml}$ (total mass injected equals $25 \mathrm{mg}$ ) their percentage of satisfied patients increased to 92 per cent. Thirty milligrams of bupivacaine was given to all of our patients and we found that $12 \mathrm{ml}$ of bupivacaine 0.25 per cent provided better pain relief than $6 \mathrm{ml}$ of bupivacaine 0.5 per cent. It would seem that both volumes and mass are important to provide satisfactory pain relief in labour.

We found that $12 \mathrm{ml}$ of bupivacaine $0.25 \mathrm{per}$ cent gave satisfactory pain relief regardless of the patient's height or weight. Our findings along with others suggest that, for bupivacaine at least, there is no correlation between height ${ }^{12}$ or weight and the number of segments blocked. Bromage, ${ }^{13}$ using lidocaine, obtained results which suggested that the patient's height influenced spread of analgesia. It is possible that the different conclusion is related to the fact that two different drugs were used or that the height range in this study had too few patients at the extremes of height to assess this factor.

\section{ConClusion}

We found that, for routine continuous epidural anaesthesia in labour, $12 \mathrm{ml}$ of bupivacaine 0.25 per cent gave satisfactory pain relief. Turning the patient to the opposite side soon after the epidural catheter had been secured improved the quality of pain relief. No correlation between height or weight and spread of epidural anaesthesia was found with the two doses tested.

\section{ACKNOWLEDGEMENTS}

The authors wish to thank the Statistical Consulting Service of the University of Toronto, Dr. S. Minkin and R. Gebotys, for their invaluable assistance. The assistance of Miss Rosemary O'Connor in preparing this manuscript is also gratefully acknowledged.

\section{REFERENCES}

1. Kerr, M.G., Scott, D.B. \& Samuel, E. Studies of the Inferior Vena Cava in Late Pregnancy. $\mathrm{Br}$. Med. J. I: 532 (1964).

2. Bieniarz, J., Crottogini, J.J. \& Curuchet, E. Aortocaval Compression by the Uterus in Late Human Pregnancy. Am. J. Obstet. Gynecol. 100: 203-217 (1968).

3. MARX, G.F. Aortocaval Compression: Incidence and Prevention. Bull. N.Y. Acad. Med. 50:443 (1974).

4. Huovinen, K. \& Teramo, K. Effect of Maternal Position on Fetal Heart Rate During Epidural Analgesia. Br. J. Anaesth. 51: 767 (1979).

5. WRIGHT, R.G. \& ShNider, S. M. Hypotension and Regional Anesthesia in Obstetrics, Anesthesia for Obstetrics. Edited by Shnider, S.M. and Levinson, G. Baltimore, Williams and Wilkins, 1979, pp. 279-287.

6. Homes, G. \& Mathews, B. Introduction to Clini- 
cal Neurology. 3rd Ed. Edinburgh: Churchill Livingstune, 1968, p. 67.

7. Steffenson, J. Inhalation Analgesia - Nitrous Oxide, Methoxyflurane, Obstetrical Anesthesia. Edited by Shnider, S.M. New York, Robert E. Krieger Publishing Company, 1970, p. 83.

8. Fienberg, S.E. The Analysis of Multidimensional Contingency Tables. Ecology 51:419 (1970).

9. Grundy, E.M., Nageswara, L. \& Winnie, A.P. Epidural Anesthesia and the Lateral Position. Anesth. Analg. (Cleve.) 57: 95 (1978).

10. Sharrock, N.E. \& Greenidge, J. Epidural Dose
Response in Pregnant and Non-Pregnant Patients. Anesthesiology 51: \$298(1979).

11. Bleyaert, A., Soetens, M., Vaes, L., et al. Bupivacaine, 0.125 per cent, in Obstetric Epidural Analgesia: Experience in Three Thousand Cases. Anesthesiology 51: 435 (1979)

12. Sharrock, N.E. The Influence of Height on Epidural Spread in Young and Old Patients. Anesthesiology 51: S224 (1979).

13. Bromage, P.R. Spread of Analgesic Solutions in the Epidural Space and Their Site of Action: A Statistical Study. Br. J. Anaesth. 34: 161 (1962).

\section{RÉSUMÉ}

Le retentissement de la position latérale et du volume d'agent injecté sur la propagation de l'anesthésie épidurale a été évalué sur 131 parturientes en bonne santé.

L'anesthésie épidurale a été réalisée au niveau de $\mathrm{L}_{3} \mathrm{~L}_{4}$ et un cathéter inséré dans l'espace épidural après l'injection de l'anesthésique. Les parturientes ont été réparties au hasard en 4 groupes. Les doses utilisées ont été de $12 \mathrm{ml}$ de bupivacaine 0.25 pour cent et $6 \mathrm{ml}$ de bupivacaine 0.5 pour cent. Les patientes ont été laissées dans la mème position qu'elles étaient lors du blocage (groupes I et III) ou retournées du côté opposé une fois l'injection épidurale terminale (groupes II et IV). Le niveau sensitif et l'évaluation du soulagement obtenu par la mère ont été déterminée 15 à 20 minutes après l'injection. Chaque évaluation a été effectuée par un observateur compétent mais qui ne savait pas à quel groupe la patiente appartenait.

Le maintien de la position latérale après l'induction de l'anesthésié ćpidurale est compatible avec une anesthésie satisfaisante pour le travail. Douze $\mathrm{ml}$ de bupivacaine 0.25 pour cent produisent une meilleure analgésie que $6 \mathrm{ml}$ de bupivacaine à 0.5 pour cent bien que la masse injectée sont la même. La qualité de l'analgésie est supérieure lorsque on retourne la patiente sur le côté contra-latéral après l'injection de $12 \mathrm{ml}$ de bupivacaine 0.25 pour cent. 